\title{
Online Supported Learning and Threshold Concepts in Novice Programming
}

\author{
Tze Ying Sim \\ Center for American Education \\ Sunway University \\ Bandar Sunway, Malaysia \\ Email: tzeyings@sunway.edu.my
}

\begin{abstract}
Novice programming is a challenging subject to both the students and the educators. Students struggle to comprehend the methods, and educators try their best to put forth the subject in an understandable manner. This paper presents two methods implemented to support the learning for students in a novice programming class. They are social network support and online journaling. The threshold concepts for computing are also discussed. Data collected through the online journaling method provides an indicator to the possible threshold concepts in novice programming subject. The impacts of the methods are evaluated using analysis of questionnaires responds, entries to the social networking support platform, online journaling method, and students' grade. The conclusion of this study are 1) the social support network helps students to work on the subject content, and 2) students who post on the platform have a significantly better grade. The conclusion drawn for the online journaling are 1) students who actively participated are scoring better grade in the class, and 2) online journaling method also confirms that one of the main thresholds for novice programming class is the object oriented concept. Apart from Memory and Object Oriented Programming, Multidimensional array and Methods are another two topics identified as threshold concepts for novice programming.
\end{abstract}

Keywords - curriculum development, educational technology, computer science education, engineering education

\section{Introduction}

Programming is a challenging subject. This is especially true if the programming subject is the first subject where the students are exposed to the idea of solving a problem using a programming language. The first programming classes where the majority of the students in the class are first timers is known as the novice programming class. It is common to observe that novice programming classes have about $30 \%$ to $50 \%$ failure rate [1], [2], [3]. Studies have shown that one of the most effective ways to have a higher passing rate is to have a small class where discussion towards the different effort to teach and learn programming can take place [3], [4].

As an educator, our eyes gleam with our students' when they achieved their "Aha" moments. The moment when some concepts that were previously unclear finally became clear, the knots that they cannot figure out are finally aligned and the time when they say "I finally understood what you are saying", and appreciate the subject better. Meyer and Lan termed these problematic ideas as threshold concepts [5].

This paper will first look into the literature review concerning challenges in novice programming and the threshold in computing. Next, two methods to support novice programming will be presented. They are social network support and online journaling. The methodology of the experiments will be presented. This will be followed by the result and discussion. Finally, the conclusion and future work will be presented.

\section{Literature Review}

\subsection{Threshold Concepts}

In the report Threshold Concepts and Troublesome Knowledge [5], Meyer and Lan highlighted the five characteristics of threshold concepts. They are:

1) Trans-formative understanding the threshold concept will transform the way a students perception about an idea or problem. It may even lead to a new found appreciation of certain concepts and interest.

2) Irreversible once having understood the threshold concepts, it is most likely to be permanent. It will need considerable amount of effort to unlearn this concept. One example could be having to learn how to drive or swim. Unlearning the skills is difficult.

3) Integrative the knowledge will help the learners to discover links between concepts and ideas. The learner will be able to interpret and apply the concept in various situations, and find suitable examples within its boundaries to explain differently.

4) Bounded threshold concepts might also help learners to draw boundaries pertaining the subject matter. The learners can draw the line on the limitation of the threshold concepts.

5) Troublesome threshold concepts are challenging for various reasons, for example, the pre-existing knowledge may serve as a barrier, and there are many new ideas to learn before the dots can be connected.

A quick search on the term threshold concepts in computing, returns works mainly from United Kingdom, Sweden and the United States of America. Among topics 
TABLE 1. THRESHOLD CONCEPTS IN COMPUTING

\begin{tabular}{l|c|c|c|c|c|c|c}
$\begin{array}{l}\text { Literature } \\
\text { Review }\end{array}$ & $\begin{array}{c}\text { Info } \\
\text { Hid- } \\
\text { ing }\end{array}$ & $\begin{array}{c}\text { Ab- } \\
\text { strac- } \\
\text { tion }\end{array}$ & OOP & $\begin{array}{c}\text { Point- } \\
\text { ers }\end{array}$ & $\begin{array}{c}\text { Mem- } \\
\text { ory }\end{array}$ & $\begin{array}{c}\text { Dy- } \\
\text { namic } \\
\text { Ex- } \\
\text { tion }\end{array}$ & $\begin{array}{c}\text { De- } \\
\text { sign }\end{array}$ \\
\hline Eckerdal [7] & - & $\mathrm{X}$ & $\mathrm{X}$ & - & - & - & - \\
Boustedt [8] & - & - & $\mathrm{X}$ & $\mathrm{X}$ & - & - & - \\
Vagianou [9] & - & - & - & $\mathrm{X}$ & $\mathrm{X}$ & - & - \\
Sorva [10] & $\mathrm{X}$ & - & $\mathrm{X}$ & - & - & $\mathrm{X}$ & - \\
Zander [11] & - & - & $\mathrm{X}$ & - & $\mathrm{X}$ & - & $\mathrm{X}$
\end{tabular}

suggested to be part of threshold concepts in Computer Science are presented in Table 1. However, this perspective is not agreeable by all researchers, as there is also research that did not identify any particular concepts to be "the" difficult concepts in programming [6].

Based on Table 1, excluding the design concept, the categorization can be further simplified to two main concepts. They are Object Oriented Programming (OOP) encompassing Information Hiding and Abstraction; and Memory with Pointers and Dynamic Execution as part of the memory threshold concept. The two main threshold concepts are OOP and memory.

\subsection{Support for Novice Programming}

There are three main technical challenges to a novice programming course. The challenges are listed below:

1) propose a solution to the problem,

2) construct the solution in a formal manner

3) implementing the solution using a new tool (the development environment).

In order to propose the solution and construct the solution in a formal order, the suitable steps arranged in the correct order are important [12]. Having formalized the solution, the students would need to implement it in a tool that is new to them. When considering each of the challenges as steps a student need to go through before proposing a solution, they are all considered as higher order thinking activities. Therefore, it is not surprising to find many works around the topic supporting novice programming course.

Different research has been conducted to improve the learning experience of novice programmers. They include using graphical notation to learn programming, study on the different errors to identify most common errors, providing diverse feedback to the programming work and even providing social communication support for students to interact with each other [13], [14], [15], [16], [17], [18], [19], [20], [21], [22], [23], [24], [25]. Apart from identifying the methods to be implemented within a course, it is always important to consider the resources available [26]. Not having the suitable resources when undertaking a method that is resource intensive, would not provide the intended result.

One of the most common theme identified in help students to make progress in their programming experiences is the social support. Students can overcome the challenges better when they have peers or instructors who are able to provide assistance in their learning [12],
[27], [28]. There had been studies on using the learn management system (LMS) vs. a social network support (SNS) to facilitate the class communication. Examples of SNS include Facebook, Twitter, MySpace, Google+ etc. The most popular SNS is Facebook with the participation of $80 \%$ of students in the institute of higher education in Malaysia. There are two sides to the implementation of SNS. Firstly, studies have shown that students activities on Facebook correlate negatively to the academic grades [29], [30].The studies include all activities on Facebook. On the other hand, as so many students are active on Facebook, it is a more effective tool for communication as compared to the learn management system [31] [24] [27].

To understand the difficulties faced by students in the class, feedbacks can be collected after the class. There are various ways of collecting feedback, from using physical paper to online question and answer [26], [32], [33], [34], [35]. Journaling allows the student to reflect on the topics covered, the content they understood and the challenges they faced. Journaling can also be used as a source to obtain insights from the students [12].

\section{Methodology}

\subsection{Context and Participation}

The research is conducted over three semesters Spring 2014, Fall 2014, and Spring 2015. For each semester, the students are asked to join a Facebook group during the first week of class. The Facebook group is first set as a public group so that the students can participate without having to be a friend of the lecturer or other classmates. The group setting is then changed to closed group after the second week of class. The students are not awarded points, and the participants are voluntary. The first post is generally by one of the students or the lecturer to welcome the rest of the class into the Facebook group.

During Spring 2014, when the social networking support was introduced, students are more guided to discuss the social networking platform. During the implementation in Fall 2014, and Spring 2015, the participation was more organic and with fewer reminders and requests for students to post their feedback on the social networking platform.

In Spring 2015, students were requested to write an online learning journal after every class. The online journaling was done via a Google form. The students are required to key in the student identification, name, content covered for the day, challenging content for the day, and his/her reflection. The "reflection" category was selected for analysis as it has a variety of input depending on what is essential for the students. The entry from the students is used to provide weekly feedback to the students. Difficult areas will be revisited in the coming classes.

\subsection{Data Collection}

Different types of data are used for this research. They are the 1) academic grades; 2) Facebook participation; 3) online journaling participation; 4) feedback via a survey and 5) observation from the lecturer. To establish a baseline for the class, the Cumulative Grade Point Average 
TABLE 2. BASELINE ANALYSIS

\begin{tabular}{|c|c|c|c|c|}
\hline & & $\begin{array}{l}\text { CGPA } \\
\text { Before }\end{array}$ & $\begin{array}{c}\text { CGPA } \\
\text { After }\end{array}$ & $\begin{array}{l}\text { CSCP } \\
\text { Mark }\end{array}$ \\
\hline \multirow[t]{3}{*}{$\begin{array}{l}\text { CGPA } \\
\text { Before }\end{array}$} & $\begin{array}{c}\text { Corr. } \\
\text { Coefficient }\end{array}$ & 1.000 & $0.860 * *$ & $0.591 * *$ \\
\hline & $\begin{array}{c}\text { Sig. } \\
\text { (2-tailed) }\end{array}$ & . & 0.000 & 0.000 \\
\hline & $\mathrm{N}$ & 62 & 62 & 62 \\
\hline \multirow[t]{3}{*}{$\begin{array}{l}\text { CGPA } \\
\text { After }\end{array}$} & $\begin{array}{c}\text { Corr. } \\
\text { Coefficient }\end{array}$ & $0.850 * *$ & 1.000 & $0.729 * *$ \\
\hline & $\begin{array}{c}\text { Sig. } \\
\text { (2-tailed) }\end{array}$ & 0.000 & . & 0.000 \\
\hline & $\mathrm{N}$ & 62 & 62 & 62 \\
\hline \multirow[t]{3}{*}{$\begin{array}{l}\text { CSCP } \\
\text { Mark }\end{array}$} & $\begin{array}{c}\text { Corr. } \\
\text { Coefficient }\end{array}$ & 0.591 & $0.729 * *$ & 1.000 \\
\hline & $\begin{array}{c}\text { Sig. } \\
\text { (2-tailed) }\end{array}$ & 0.000 & 0.000 & . \\
\hline & $\mathrm{N}$ & 62 & 62 & 62 \\
\hline
\end{tabular}

(CGPA) before the semester starts (pre-semester), is used to compare with the CGPA after the semester ends (postsemester). Under the usual circumstances, there should be a correlation between the grade before the semester starts as to after the semester ends. A strong correlation indicates that the performance of the students is consistent. Next, to access if the students performance in the class is consistent, the final grade for the novice programming class is compared to the pre and post semesters CGPA. The grades should correlate with the CGPA. The correlation will establish the baseline for the measurement.

Next, the activities of the Facebook group will be analyzed. The activities are categorized as a post, comment and like. The activities by the students in the group will be accounted for individually. Each post will be accounted to individual postings. If a member makes two comments in a post, then two comments will be accounted to the individual, the same applies to like (including likes on a comment). However, the quality of the post and comment are not categorized. As long as there is participation, then it is accounted.

A survey to measure the effectiveness of using the Facebook group as well as online Journaling as a teaching and learning tool is conducted at the end of the semester. Even though the Facebook group was conducted over a period of three semesters, only the data for Spring 2014 and Fall 2014 are available for the evaluation. Online journaling was only conducted in Spring 2015. Therefore, only one set of data is available for analysis. Analysis based on the content of the online journaling will also be discussed. The lecturers observation will be included in drawing the conclusions.

\section{Results and Discussion}

To establish the baseline of students grade, the CGPA pre-and post the semester are compared for correlation (see Table 2). Using Spearman model, it is found that both CGPA pre-and post the semester have a significant correlation at the p-value of 0.000 . This means students who are doing well continue to do well. The next baseline to be considered is if the grade for novice programming is also consistent. Based on the correlations analysis, the grade for novice programming correlates with both the
TABLE 3. Correlation BetweEn FB PARTiCipation AND GRAdE

\begin{tabular}{|c|c|c|c|c|}
\hline & & $\begin{array}{l}\text { CSCP } \\
\text { Before }\end{array}$ & $\begin{array}{l}\text { CSCP } \\
\text { After }\end{array}$ & $\begin{array}{l}\text { CSCP } \\
\text { Mark }\end{array}$ \\
\hline \multirow[t]{3}{*}{ Post } & $\begin{array}{c}\text { Corr. } \\
\text { Coefficient }\end{array}$ & 0.225 & $0.395 * *$ & $0.427 * *$ \\
\hline & $\begin{array}{c}\text { Sig. } \\
\text { (2-tailed) }\end{array}$ & 0.078 & 0.001 & 0.001 \\
\hline & $\mathrm{N}$ & 62 & 62 & 62 \\
\hline \multirow[t]{3}{*}{$\begin{array}{l}\text { Com- } \\
\text { ment }\end{array}$} & $\begin{array}{c}\text { Corr. } \\
\text { Coefficient }\end{array}$ & 0.072 & 0.209 & $0.453^{* *}$ \\
\hline & $\begin{array}{c}\text { Sig. } \\
\text { (2-tailed) }\end{array}$ & 0.580 & 0.103 & 0.00 \\
\hline & $\mathrm{N}$ & 62 & 62 & 62 \\
\hline \multirow[t]{3}{*}{ Like } & $\begin{array}{c}\text { Corr. } \\
\text { Coefficient }\end{array}$ & 0.134 & 0.213 & $0.431 * *$ \\
\hline & $\begin{array}{c}\text { Sig. } \\
\text { (2-tailed) }\end{array}$ & 0.299 & 0.096 & 0.00 \\
\hline & $\mathrm{N}$ & 62 & 62 & 62 \\
\hline
\end{tabular}

TABLE 4. STUdENTS' FEEDBACK ON FACEBOOK GROUP TECHNIQUE IN SPRING 2014

\begin{tabular}{l|c|c|c|c|c} 
Spring 2014 & $\begin{array}{c}\text { Strongly } \\
\text { Agree }\end{array}$ & Agree & $\begin{array}{c}\text { Neu- } \\
\text { tral }\end{array}$ & $\begin{array}{c}\text { Dis- } \\
\text { agree }\end{array}$ & $\begin{array}{c}\text { Strongly } \\
\text { Dis- } \\
\text { agree }\end{array}$ \\
\hline $\begin{array}{l}\text { Class Discussion } \\
\begin{array}{l}\text { Work On Course } \\
\text { Content }\end{array}\end{array}$ & 19 & 12 & N/A & N/A & N/A \\
& 14 & 17 & N/A & N/A & N/A
\end{tabular}

pre-and post CGPA at the p-value of 0.000 . Having all the three grades correlating to each other indicates that the performance of the student is consistent.

\section{1. online Social Network System}

Having the baseline established, we moved on to observe the participation of the students in the SNS - the Facebook group. The correlation between the activities and students' grade are presented in Table 3. It is observed that the novice programming grade has a significant correlation to all the three activities, namely post, comment and like. This means that students who participated in the online activities are also obtaining a better grade for the novice programming subject. The pre-semester CGPA did not correlate with any of the activities. This can be translated to the students who participated in the activities do not necessarily have a better grade. On the contrary, the post-semester CGPA correlates with posting on the Facebook group with the p-value at 0.001. As the correlation only happens to the students who post, this might give an indicator that students who post have better programming grade that also impacted the post-semester CGPA.

Based on the survey provided, all the students in Spring 2014 agreed that the implementation of the Facebook group has positively influenced the teaching and learning engagement of the class (see Table 4). The survey has two questions. The students were asked if the implementation has facilitated the class discussion, and encouraged them to work on the course content. The response of the students is recorded in the following table. All the students either strongly agreed or agreed with both statements. 
TABLE 5. STUdENTS' FEEDBACK ON FACEBOOK GROUP TECHNIQUE IN FALL 2014

\begin{tabular}{l|c|c|c|c|c} 
Fall 2014 & $\begin{array}{c}\text { Strongly } \\
\text { Agree }\end{array}$ & Agree & $\begin{array}{c}\text { Neu- } \\
\text { tral }\end{array}$ & $\begin{array}{c}\text { Dis- } \\
\text { agree }\end{array}$ & $\begin{array}{c}\text { Strongly } \\
\text { Dis- } \\
\text { agree }\end{array}$ \\
\hline Class Discussion & 13 & 8 & 0 & 1 & 0 \\
$\begin{array}{l}\text { Raise Question } \\
\text { Interactive Class }\end{array}$ & 12 & 7 & 2 & 1 & 0 \\
$\begin{array}{l}\text { Work On Course } \\
\text { Content }\end{array}$ & 11 & 5 & 5 & 1 & 0 \\
$\begin{array}{l}\text { Out Of Class } \\
\text { Engagement }\end{array}$ & 12 & 6 & 2 & 2 & 0
\end{tabular}

TABLE 6. STUDENTS' PARTICIPATION ON FACEBOOK GROUP

\begin{tabular}{l|c|c|c} 
Spring 2014 & $\begin{array}{c}\text { Sum of } \\
\text { Post }\end{array}$ & $\begin{array}{c}\text { Sum of } \\
\text { Com- } \\
\text { ment }\end{array}$ & $\begin{array}{c}\text { Sum of } \\
\text { Like }\end{array}$ \\
\hline Spring 2014 & 48 & 324 & 257 \\
Fall 2014 & 16 & 100 & 23 \\
Fall 2014 & 16 & 42 & 78
\end{tabular}

TABLE 7. CORRELATION BETWEEN POSTS FOR ONLINE JOURNALING AND GRADES

\begin{tabular}{l|c|c|c|c} 
& & $\begin{array}{c}\text { CSCP } \\
\text { Before }\end{array}$ & $\begin{array}{c}\text { CSCP } \\
\text { After }\end{array}$ & $\begin{array}{c}\text { CSCP } \\
\text { Mark }\end{array}$ \\
\hline $\begin{array}{l}\text { Posts } \\
\text { for }\end{array}$ & $\begin{array}{c}\text { Correlation } \\
\text { Sig. }\end{array}$ & $0.632 * *$ & $0.550 * *$ & $0.700 * *$ \\
$\begin{array}{l}\text { online } \\
\text { Journal- } \\
\text { ing }\end{array}$ & $\mathrm{N}$ & 0.000 & 0.001 & 0.000 \\
& & 31 & 31 & 31
\end{tabular}

For Fall 2014, three additional questions were added (see Table 5). They were also asked if the Facebook group helped them to raise questions, interact in the class and facilitated the out of class engagement. It is observed that $85 \%$ of the class agreed or strongly agreed to all the statements. When observing the data for participation across the three semesters (see Table 6), it is observed that as compared to the other two semesters, the number of posting was the highest in Spring 2014. This may have influenced the decline of $100 \%$ of strongly agreed and agreed in Spring 2014, to 85\% in Fall 2014.

Among the post by students in the Facebook group are concepts related to the threshold concepts. The students were looking for information on the explanation of Pseudo code, solving problems, and making the code more efficient, Object Oriented Programming, etc. Students will also pose questions, and instead of having the lecturer to answer, the peers are answering the questions. They were also sharing videos and even jokes that they find helpful in understanding the course content.

\subsection{Online Journaling}

Having established that the performance of the students is consistent, the effectiveness of online journaling is discussed. There is a correlation between the number of posting in the online journal to the marks for the novice programming subject at the p-value of 0.000 (see Table 7). There is also a correlation between the number of posting and the students CGPA after the semester at the p-value of 0.001. Both correlations mentioned above, can
TABLE 8. STUdents' FeEdBACK ON THE UsAge OF ONLINE JOURNALING

\begin{tabular}{l|c|c|c|c|c} 
& $\begin{array}{c}\text { Strongly } \\
\text { Agree }\end{array}$ & Agree & $\begin{array}{c}\text { Neu- } \\
\text { tral }\end{array}$ & $\begin{array}{c}\text { Dis- } \\
\text { agree }\end{array}$ & $\begin{array}{c}\text { Strongly } \\
\text { Dis- } \\
\text { agree }\end{array}$ \\
\hline $\begin{array}{l}\text { The usage of } \\
\text { journaling helps } \\
\text { me to reflect on } \\
\text { the content } \\
\text { covered in the } \\
\text { class }\end{array}$ & 10 & 10 & 3 & 0 & 0 \\
$\begin{array}{l}\text { Receiving } \\
\text { Feedback on } \\
\text { journaling } \\
\text { motivates me to } \\
\text { work on the } \\
\text { course content }\end{array}$ & 7 & 13 & 3 & 0 & 0
\end{tabular}

TABLE 9. CORRELATION BETWEEN POSTS FOR ONLINE JOURNALING AND GRADES

\begin{tabular}{|c|c|c|c|c|}
\hline & & $\begin{array}{l}\text { FB } \\
\text { Post }\end{array}$ & $\begin{array}{c}\text { FB } \\
\text { Com- } \\
\text { ment }\end{array}$ & $\begin{array}{c}\text { FB } \\
\text { Like }\end{array}$ \\
\hline $\begin{array}{l}\text { Posts } \\
\text { for }\end{array}$ & Correlation & 0.221 & 0.093 & 0.343 \\
\hline online & $\begin{array}{c}\text { Sig. } \\
\text { (2-tailed) }\end{array}$ & 0.233 & 0.618 & 0.059 \\
\hline $\begin{array}{l}\text { Journal- } \\
\text { ing }\end{array}$ & $\mathrm{N}$ & 31 & 31 & 31 \\
\hline
\end{tabular}

be translated to the students who participated more in the online journaling, are also scoring better marks for the subject.

As shown in Table 8, $87 \%$ of the students who participated in the online journaling strongly agreed or agreed that the online journaling helped them to reflect on the content taught in the class. Another $13 \%$ remains neutral. The same applies to online journaling motivating them to work on the course content.

There is no correlation between the posting in the Facebook group to online journaling (see Table 9). Most if not all the students participated in the online journaling because it was requested in the class. Therefore, the students are sort of "forced" to participate in the online journaling. The Facebook group posting, on the other hand, is more of a personal initiative. The correlation between activities in Facebook group and the grade, may indicate that students who strive to do well will take more initiative in class participation. However, the Facebook group as a platform for communications seems to be a useful platform.

The comments by the students are categorized into six different categories. They are:

1) Positive Content (pc) - the students expressed that they are able to master the content for the day.

2) Positive Feeling (pf) - the students expressed that they enjoyed the class. It could be a compliment to a good class, helping each other in the class etc, but it has no direct connection to the topics taught on that day.

3) Moving Forward (mf) - students indicated that they need to put in more effort in the future to tackle the subject. For example, study more, do more revision, etc. 


\begin{tabular}{|l|r|r|r|r|r|r|r|}
\hline Dates & \multicolumn{1}{c|}{ pc } & \multicolumn{1}{c|}{ pf } & \multicolumn{1}{c|}{ mf } & \multicolumn{1}{c|}{ o } & \multicolumn{1}{c|}{ cc } & nf & $\begin{array}{l}\text { Participation } \\
\text { for 100\% }\end{array}$ \\
\hline $3 / 25 / 2015$ & $3 \%$ & $48 \%$ & $3 \%$ & $23 \%$ & $23 \%$ & $0 \%$ & 31 \\
\hline $3 / 30 / 2015$ & $10 \%$ & $28 \%$ & $3 \%$ & $34 \%$ & $24 \%$ & $0 \%$ & 29 \\
\hline $4 / 01 / 2015$ & $21 \%$ & $32 \%$ & $0 \%$ & $39 \%$ & $7 \%$ & $0 \%$ & 28 \\
\hline $4 / 06 / 2015$ & $22 \%$ & $13 \%$ & $6 \%$ & $47 \%$ & $13 \%$ & $0 \%$ & 32 \\
\hline $4 / 08 / 2015$ & $16 \%$ & $4 \%$ & $12 \%$ & $48 \%$ & $20 \%$ & $0 \%$ & 25 \\
\hline $4 / 13 / 2015$ & $30 \%$ & $15 \%$ & $11 \%$ & $33 \%$ & $11 \%$ & $0 \%$ & 27 \\
\hline $4 / 15 / 2015$ & $14 \%$ & $23 \%$ & $5 \%$ & $45 \%$ & $14 \%$ & $0 \%$ & 22 \\
\hline $4 / 20 / 2015$ & $15 \%$ & $8 \%$ & $8 \%$ & $62 \%$ & $8 \%$ & $0 \%$ & 26 \\
\hline $4 / 22 / 2015$ & $26 \%$ & $4 \%$ & $4 \%$ & $57 \%$ & $4 \%$ & $4 \%$ & 23 \\
\hline $4 / 27 / 2015$ & $12 \%$ & $8 \%$ & $4 \%$ & $54 \%$ & $19 \%$ & $4 \%$ & 26 \\
\hline $4 / 29 / 2015$ & $14 \%$ & $0 \%$ & $19 \%$ & $29 \%$ & $33 \%$ & $5 \%$ & 21 \\
\hline $5 / 06 / 2015$ & $8 \%$ & $4 \%$ & $40 \%$ & $8 \%$ & $16 \%$ & $24 \%$ & 25 \\
\hline $5 / 18 / 2015$ & $0 \%$ & $5 \%$ & $32 \%$ & $50 \%$ & $5 \%$ & $9 \%$ & 22 \\
\hline $5 / 20 / 2015$ & $21 \%$ & $7 \%$ & $21 \%$ & $29 \%$ & $21 \%$ & $0 \%$ & 14 \\
\hline $5 / 25 / 2015$ & $29 \%$ & $0 \%$ & $14 \%$ & $29 \%$ & $29 \%$ & $0 \%$ & 7 \\
\hline $5 / 27 / 2015$ & $8 \%$ & $13 \%$ & $13 \%$ & $58 \%$ & $8 \%$ & $0 \%$ & 24 \\
\hline $6 / 01 / 2015$ & $10 \%$ & $14 \%$ & $10 \%$ & $57 \%$ & $0 \%$ & $10 \%$ & 21 \\
\hline $6 / 03 / 2015$ & $4 \%$ & $8 \%$ & $8 \%$ & $56 \%$ & $16 \%$ & $8 \%$ & 25 \\
\hline $6 / 10 / 2015$ & $0 \%$ & $0 \%$ & $50 \%$ & $50 \%$ & $0 \%$ & $0 \%$ & 2 \\
\hline $6 / 15 / 2015$ & $0 \%$ & $0 \%$ & $21 \%$ & $21 \%$ & $53 \%$ & $5 \%$ & 19 \\
\hline $6 / 22 / 2015$ & $0 \%$ & $0 \%$ & $16 \%$ & $47 \%$ & $37 \%$ & $0 \%$ & 19 \\
\hline $6 / 24 / 2015$ & $0 \%$ & $0 \%$ & $0 \%$ & $100 \%$ & $0 \%$ & $0 \%$ & 1 \\
\hline $7 / 01 / 2015$ & $0 \%$ & $100 \%$ & $0 \%$ & & $0 \%$ & $0 \%$ & 1 \\
\hline Grand Total & 60 & 62 & 55 & 197 & 79 & 16 & 469 \\
\hline & & & & & & \\
\hline
\end{tabular}

Figure 1. Categorization of Feedback in online Journaling.

4) Others (o) - There is no comment in the reflection section, or the comments are not relevant to the content covered. For example, the air-con is out, I missed the toilet break, etc.

5) Challenging Content (cc) - the students expressed difficulty in comprehending the content covered for the day.

6) Negative Feeling (nf) - students expressed a negative feeling about the class. For example, this is so hard, I am going to fail, etc.

The participation for online journaling was slightly higher at the beginning of the semester as compared to the end of the semester (see Figure 1). This is due to 7 students withdrawing from the subject at week 10 . The few dates with lower response were done without the reminder from the lecturer. They are 20/5, 25/5, 10/6, 24/6 and $1 / 7$.

The online journaling provides insight on what is happening in students mind and life. Figure 1 summarizes the comments in each of the categories. As the participation on 10th June, 24th June, and 1st July are low; they are excluded from the analysis. The comments for "others" category are also excluded as they are not related to the course content. These data are italicized in Figure 1. The higher percentage cells are in a darker shade. During the beginning of the semester, the students are very positive about the subject, $48 \%$ of the students indicated positive feeling and $23 \%$ indicated that the content would be challenging. The next spike of number is at $33 \%$ for challenging content on the 29th April. On this day the chapter "method" was covered. This is then followed by $40 \%$ for moving forward the next week, where the first test was conducted. Many of the students wrote in their reflection that they should be more prepared for the first test. That week also records the highest peak for the negative feeling category. When the topic array was introduced on the 20th May, it records $21 \%$ for challenging content. $29 \%$ was recorded for challenging content the next week, on the 25th May, where multidimensional was introduced. Moving along the weeks, the next peak is on the 15th June. The online journal recorded $53 \%$ for challenging content. The topic covered is OOP. The same goes for the week after at $37 \%$.

From the threshold concept discussed in Section 2.1, the two main ideas identified are OOP and memory. From the Figure 1, it can be concluded that the concept memory that was covered during the first half of the semester, is not as challenging as OOP. One of the possible reason to this is the physical demonstration of memory concept using cups of different sizes in the class has contributed to the understanding of the students. The other two threshold concepts recorded through the experiment are methods and multidimensional arrays.

\section{Conclusion and Future Work}

This research discussed the implementation of two online tools in detailed. They were the Facebook group as a support network system and online journaling.

Section 2.2 indicates that social support is an important element in helping novice programmer to do better. Therefore, the Facebook group was implemented to support the students. From the data, there is a significant correlation at the p-value of 0.000 between the number of posting and the students' grade.

Next, through the implementation of online journaling the following findings were discovered:

- There is a correlation between participation in online journaling and the students' grade for the subject at the p-value of 0.001 .

- The threshold concepts indicated are methods, multidimensional array and OOP.

- The threshold concept memory covered during the second and third week of the class did not pose to be a problem in this class.

For future work, there are a few things worth investigating. First is the notion of OOP first. Should OOP first be advocated as there are so many concepts bundled with OOP. Students in novice programming classes have enough threshold concepts to deal with even without OOP. Next, is the idea of physical demonstration for memory concept. Contrary to the literature review, students in the classes did not indicate memory as one of the challenges. Finally, having concluded students participation in activities, data analytics can be built based on these rule to monitor and predict students' performance.

\section{References}

[1] J. Bennedsen and M. E. Caspersen, "Failure rates in introductory programming," ACM SIGCSE Bulletin, vol. 39, no. 2, p. 32, 2007. [Online]. Available: http://portal.acm.org/citation.cfm?doid=1272848.1272879

[2] A. Gomes and A. Mendes, "A teacher's view about introductory programming teaching and learning: Difficulties, strategies and motivations," in Proceedings - Frontiers in Education Conference, FIE, 2015. 
[3] C. Watson and F. W. Li, "Failure rates in introductory programming revisited," Proceedings of the 2014 conference on Innovation \& technology in computer science education - ITICSE '14, pp. 39-44, 2014. [Online]. Available: http://dl.acm.org/citation.cfm?doid=2591708.2591749

[4] X. Suo, "Session T2A Toward More Effective Strategies in Teaching Programming for Novice Students," in IEEE International Conference on Teaching, Assessment, and Learning for Engineering (TALE), Hong Kong, 2012, pp. T2A1-T2A3.

[5] J. Meyer and R. Land, "Threshold Concepts and Troublesome Knowledge: Linkages to Ways of Thinking and Practising within the Disciplines," University of Edingburgh, Edinburgh, Tech. Rep., 2003.

[6] J. E. Moström, J. Boustedt, A. Eckerdal, R. McCartney, K. Sanders, L. Thomas, and C. Zander, "Computer science student transformations," ACM SIGCSE Bulletin, vol. 41, no. 3, p. 181, 2009.

[7] A. Eckerdal, R. McCartney, J. E. Moström, M. Ratcliffe, K. Sanders, and C. Zander, "Putting threshold concepts into context in computer science education," ACM SIGCSE Bulletin, vol. 38, no. 3, p. 103,2006

[8] J. Boustedt, A. Eckerdal, R. McCartney, J. E. Moström, M. Ratcliffe, K. Sanders, and C. Zander, "Threshold concepts in computer science," ACM SIGCSE Bulletin, vol. 39, no. 1, p. 504, 2007.

[9] E. Vagianou, "Program working storage: a beginner's model," Proceedings of the 6th Baltic Sea conference on Computing education research Koli Calling 2006 - Baltic Sea '06, p. 69, 2006. [Online]. Available: http://dl.acm.org/citation.cfm?id=1315803.1315816

[10] J. Sorva, "Reflections on threshold concepts in computer programming and beyond," Proceedings of the 10th Koli Calling International Conference on Computing Education Research - Koli Calling '10, pp. 21-30, 2010. [Online]. Available: http://dl.acm.org/citation.cfm?id=1930464.1930467

[11] C. Zander, J. Boustedt, R. McCartney, J. E. Moström, K. Sanders, and L. Thomas, "Student Transformations: Are They Computer Scientists Yet?" Proceedings of the fifth international workshop on Computing education research workshop, pp. 129-140, 2009.

[12] T. Y. Sim, "Exploration on the impact of online supported methods for novice programmers," 2015 IEEE Conference on e-Learning, e-Management and e-Services, IC3e 2015, pp. 158-162, 2016.

[13] A. Altadmri and N. C. C. Brown, "37 Million Compilations: Investigating Novice Programming Mistakes in Large-Scale Student Data," in SIGCSE '15 Proceedings of the 46th ACM Technical Symposium on Computer Science Education, 2015, pp. 522-527.

[14] H. Amer and W. Ibrahim, "Using the iPad as a pedagogical tool to enhance the learning experince for novice programing students," in IEEE Global Engineering Education Conference, EDUCON, 2014.

[15] D. S. Campos, A. J. Mendes, M. J. Marcelino, D. J. Ferreira, and L. M. Alves, "A multinational case study on using diverse feedback types applied to introductory programming learning," in Proceedings - Frontiers in Education Conference, FIE, 2012.

[16] M. Ichinco and C. Kelleher, "Exploring novice programmer example use," in Proceedings of IEEE Symposium on Visual Languages and Human-Centric Computing, VL/HCC, 2015.

[17] M. J. Lee and A. J. Ko, "Investigating the role of purposeful goals on novices' engagement in a programming game," in Proceedings of IEEE Symposium on Visual Languages and Human-Centric Computing, VL/HCC, 2012.

[18] M. Maleko, M. Hamilton, D. D'Souza, and F. Scholer, "Understanding and analysing novice programmer interactions in a facebook programming group," Proceedings - 2014 International Conference on Teaching and Learning in Computing and Engineering, LATICE 2014, pp. 112-119, 2014.

[19] A. R. Mohamad Gobil, Z. Shukor, and I. A. Mohtar, "Novice difficulties in selection structure," in Proceedings of the $2009 \mathrm{In}$ ternational Conference on Electrical Engineering and Informatics, ICEEI 2009, 2009.

[20] K. Roy, W. C. Rousse, and D. B. Demeritt, "Comparing the mobile novice programming environments: App Inventor for Android vs. GameSalad," in Proceedings - Frontiers in Education Conference, FIE, 2012.
[21] R. Junco, "The relationship between frequency of Facebook use, participation in Facebook activities, and student engagement,' Computers and Education, vol. 58, pp. 162-171, 2012.

[22] I. Boada, J. Soler, F. Prados, and J. Poch, "A teaching/learning support tool for introductory programming courses," Information Technology Based Proceedings of the Fifth International Conference on Higher Education and Training, 2004. ITHET 2004., pp. 604-609, 2004.

[23] O. Hazzan and Y. Dubinsky, "Teaching a software development methodology: the case of extreme programming," Proceedings 16th Conference on Software Engineering Education and Training, 2003. (CSEE\&T 2003)., 2003.

[24] T. Y. Sim and B. Vogel-Heuser, "Reviews and findings on implementing active learning in a large class environment for Mechatronics and Computer Science students," Education Engineering (EDUCON), 2010 IEEE, 2010.

[25] H. Zhu, "Methodology First and Language Second : A Way to Teach Object-Oriented Programming," in Companion of the 18th Annual ACM SIGPLAN Conference on Object-oriented Programming, Systems, Languages, and Applications, 2003, pp. 140-147.

[26] T. Y. Sim, "Effectiveness of the Methods for Engineering Courses in a Large Non-homogenous Class Setting: With Regards to the Specific Disciplines - Computer Science and Mechatronics in Learning Embedded System," Ph.D. dissertation, University of Kassel, 2010.

[27] M. Maleko, M. Hamilton, and D. D'Souza, "Access to mobile learning for novice programmers via social networking sites," 2012 7th International Conference on Computer Science \& Education (ICCSE), no. Iccse, pp. 1533-1538, 7 2012. [Online]. Available: http://ieeexplore.ieee.org/lpdocs/epic03/wrapper.htm?arnumber=6295355

[28] R. McCartney, A. Eckerdal, J. E. Mostrom, K. Sanders, and C. Zander, "Successful students' strategies for getting unstuck," ACM SIGCSE Bulletin, vol. 39, no. 3, p. 156, 2007.

[29] W. W. Goh, "Students' behavior and perception of using Facebook as a learning tool," 2013 8th International Conference on Computer Science \& Education, no. Iccse, pp. 731-736, 4 2013. [Online]. Available: http://ieeexplore.ieee.org/lpdocs/epic03/wrapper.htm?arnumber=6554004

[30] S. Jamil, F. Zehra, R. Naqvi, and S. Bhamani, "Impact of facebook intensity on academic grades of private university students," in 5th International Conference on Information and Communication Technologies p. 1-10, 2013, pp. 1-10.

[31] M. Maleko, D. Nandi, M. Hamilton, D. D'Souza, and J. Harland, "Facebook versus Blackboard for Supporting the Learning of Programming in a Fully Online Course: The Changing Face of Computing Education," 2013 Learning and Teaching in Computing and Engineering, pp. 83-89, 3 2013. [Online]. Available: http://ieeexplore.ieee.org/lpdocs/epic03/wrapper.htm?arnumber=6542243

[32] P. J. Denning, "The social life of innovation," Communications of the ACM, vol. 47, no. 4, p. 15, 2004.

[33] V. Simpson-Beck, "Assessing classroom assessment techniques," Active Learning in Higher Education, vol. 12, no. 2, pp. 125-132, 2011.

[34] J. Robertson, "Rethinking how to teach programming to newcomers," Communications of the ACM vol. 57, no. 5, pp. 18-19, 2014. [Online]. Available: http://dl.acm.org/citation.cfm?doid=2594413.2591203

[35] Socrative, "Socrative," 2015. [Online]. Available: http://socrative.com/ 